\title{
The survival and behavioural responses of a near-shore chironomid and oligochaete to declining water levels and sandy substratum drying
}

\author{
Małgorzata Poznańska • Dominika Werner - Izabela Jabłońska-Barna • Tomasz Kakareko • \\ Klaudia Ung Duong · Anna Dzierżyńska-Białończyk · Jarosław Kobak
}

Received: 30 March 2016/Revised: 12 September 2016/ Accepted: 24 September 2016/Published online: 4 October 2016

(C) The Author(s) 2016. This article is published with open access at Springerlink.com

\begin{abstract}
Organisms inhabiting shallow near-shore waters experience emersion during water-level fluctuations, which are increasing in frequency and magnitude due to climate change and anthropogenic activities. We experimentally investigated the survival and behaviour of two common shallow-water and psammophilous invertebrates, the chironomid Stictochironomus sticticus and the oligochaete Potamothrix moldaviensis, during sandy substratum drying. We examined horizontal migrations following a decreasing water level in inclined tanks and vertical migrations into substratum. In drying tanks, the substrate was initially submerged and then water was gradually evaporated to expose the surface sediments. In control
\end{abstract}

Handling editor: Marcelo S. Moretti

M. Poznańska $(\varangle) \cdot$ D. Werner · K. Ung Duong ·

A. Dzierżyńska-Białończyk · J. Kobak

Department of Invertebrate Zoology, Faculty of Biology

and Environmental Protection, Nicolaus Copernicus

University, Lwowska 1, 87-100 Toruń, Poland

e-mail: mpoznan@umk.pl

I. Jabłońska-Barna

Department of Tourism, Recreation and Ecology,

University of Warmia and Mazury, Oczapowskiego 5,

10-718 Olsztyn, Poland

T. Kakareko

Department of Hydrobiology, Faculty of Biology and

Environmental Protection, Nicolaus Copernicus

University, Lwowska 1, 87-100 Torun, Poland tanks, the substratum remained submerged. We hypothesised that the organisms would tolerate drying (surviving at least while the substrate remained moist) and/or migrate vertically and/or horizontally under drying conditions. Chironomids were tolerant of drying, with $90 \%$ mortality occurring at the sediment water content (LWC90) of $0.3 \%$ (dry sand). They exhibited neither horizontal nor vertical migrations in response to drying. Oligochaetes were far less resistant to drying (LWC90 $=13.9 \%$, corresponding to humid sand) and did not exhibit any behavioural adaptations. Thus, our hypothesis was supported with regard to the resistance to drying of chironomids, but not that of oligochaetes. Contrary to our hypothesis, neither species exhibited behavioural adaptations to drying.

Keywords Air exposure - Water-level fluctuations · Horizontal migration · Burrowing - Stictochironomus sticticus $\cdot$ Potamothrix moldaviensis

\section{Introduction}

Water-level fluctuations are the most important factor affecting the habitat of near-shore benthic fauna (Furey et al., 2004, 2006; Brauns et al., 2008; Poznańska et al., 2010; Evtimova \& Donohue 2016). The fluctuations are caused by anthropogenic as well as natural disturbances, including disruption of natural river flows by dams (Nilsson \& Berggren, 2000), 
extensive abstraction of water resources for human consumption and industrial use (Neff et al., 2000) and/ or fast urbanisation and reduction in riparian vegetation (Verdonschot et al., 2010). Climate change also affects water-level fluctuations and is predicted to increase the onset rate, duration, frequency and intensity of future droughts (van Vliet \& Zwolsman, 2008; Nickus et al., 2010; Overpeck \& Udall, 2010; Ledger \& Milner, 2015) as well as to cause a decrease in the water level of rivers and lakes (Verdonschot et al., 2010; Abbaspour et al., 2012) and stimulate fluctuations in multiple global regions. Near-shore habitats are mainly shaped by temporary reductions of the water level, causing substratum emersion and drying, which subjects benthic invertebrates to environmental stress (Collinson et al., 1995; Boulton, 2003; Fritz \& Dodds, 2004). Therefore, benthic organisms are likely to exhibit some adaptations to emersion (McEwen \& Butler, 2010).

Physiological adaptations of organisms to emersion include desiccation resistance mechanisms, which helps prevent desiccation or allows to withstand it to a certain extent (Frouz et al., 2003; Cornette et al., 2010; Strachan et al., 2015). They are often associated with the reduction of metabolic rate (Strachan et al., 2015). One of them is aestivation, a type of dormancy, acting usually in summer and allowing to survive a hot and dry period (Strachan et al., 2015). Some invertebrates can live in a non-dormant (active) state in the emersed substratum as long as it remains humid (Poznańska et al., 2013; Verdonschot et al., 2015). A physiological adaptation of certain insect species is a modification of their life cycle by accelerating their development to emerge as adults under drying conditions (Dettinger-Klemm, 2003; Tronstad et al., 2005; Verdonschot et al., 2015). Behavioural strategies include following the decreasing water level to reach submerged areas (horizontal migration) (Richardson et al., 2002; Poznańska et al., 2013, 2015a) or burying into the moist substratum (vertical migration) (Imhof \& Harrison, 1981; Stubbington et al., 2011; Poznańska et al., 2013, 2015a; Verdonschot et al., 2015).

Chironomid larvae and oligochaetes are among the most important components of benthic macroinvertebrate communities in many reservoir types in all geographical zones, contributing to their abundance, biomass and diversity, as well as to the community functioning as key members of food webs and bioprocessors of sediments (e.g. Brinkhurst \& Cook,
1980; Armitage et al., 1995). They are also common and important in land-water transitional zones (Kornijów et al., 2003; Poznańska et al., 2010), where they may be exposed to water-level fluctuations and substratum drying.

Some studies have considered the physiological ability of chironomids to survive desiccation (e.g. Watanabe et al., 2002; Cornette et al., 2010; Frouz \& Matěna, 2015), as well as the state of benthic assemblages (including chironomids) before and after drying of intermittent streams and ponds (e.g. Bazzanti et al., 1997; Boulton, 2003; Lind et al., 2006; Datry et al., 2012). Yet, the phenomenon of resistance of chironomids to substratum drying is also essential in reservoirs that experience short-term water-level fluctuations, when the substratum drying is not as long and sediment moisture content is the key factor determining tolerance of particular species to emersion (Stubbington \& Datry, 2013; Strachan et al., 2015). European chironomid Polypedilum tritium (Walker, 1856) survives summers in dry temporary pools if the sediment water content remains above 20\% (Dettinger-Klemm, 2003). Suemoto et al. (2005) found that some chironomid species survived 7 days of emersion, but they did not report their survival over longer duration, though the substratum water content on the 7th day of emersion was relatively high (17\%). Hence, precise ecological data on the resistance of particular chironomid species to direct water content in the substratum have been insufficient.

Some data concerning the responses of aquatic and semi-aquatic oligochaetes to desiccation stress are available. Dumnicka \& Koszałka (2005) observed that tubificoid Naididae (sensu Erséus et al., 2008) and semi-aquatic Enchytraeidae dominated the oligochaete community in emersed sediments and the densities of these oligochaetes were highest just after the water re-appeared. Some species of Enchytraeidae and Naididae, including tubificoid forms, are capable of reducing metabolism, aestivating and forming cysts to survive drying (Anlauf, 1990; Takada et al., 1992; Dietz-Brantley et al., 2002; Montalto \& Marchese, 2005; Maraldo et al., 2009). Vertical migrations to deeper and moister habitats have been observed in Enchytraeidae and tubificoid Naididae (Springett et al., 1970; Merle et al., 1997; Narita, 2006). Also, horizontal migrations to better oxygenated areas were found in Limnodrilus hoffmeisteri Claparede, 1862 (Fisher \& Beeton, 1975). Nevertheless, information 
about survival of oligochaetes and the related substratum water content is scarce (Strachan et al., 2015).

Here we studied the survival and behaviour of representatives of the two most important groups of benthic macroinvertebrates: a chironomid Stictochironomus sticticus (Fabricius, 1781) (Diptera: Chironomidae) and an oligochaete Potamothrix moldaviensis Vejdovsky et Mrazek, 1903 (Oligochaeta: Naididae: Tubificinae) in response to substratum drying. These species are psammophilous and inhabit the near-shore zones of dam reservoirs, which are mostly sandy (Kuklińska, 1989; 1992; Poznańska et al., 2010) and subjected to water-level fluctuations. Our aims were (1) to determine their survival in relation to the substratum water content as well as examine (2) horizontal migrations and (3) vertical migrations in response to water-level decrease and sandy substratum drying. We hypothesised that (1) species from the near-shore zone with frequent waterlevel fluctuations would be capable of surviving emersion, at least till the substratum is moist. Moreover, the tested species might also have behavioural adaptations to substratum drying, allowing them (2) to migrate horizontally following the retreating water level and/or (3) to migrate vertically (burrow) into sediments to reach more humid deeper layers.

\section{Methods}

Animals

We collected $S$. sticticus larvae (fourth instar, mean size $\pm \mathrm{SD}: \quad 9.2 \pm 0.8 \mathrm{~mm})$ and $P$. moldaviensis $(13.8 \pm 1.3 \mathrm{~mm})$ from the sandy near-shore zone of the Włocławek Reservoir, a dam reservoir on the lower River Vistula, Central Poland, (52 $\left.37^{\prime} 04^{\prime \prime} \mathrm{N} 19^{\circ} 24^{\prime} 28^{\prime \prime} \mathrm{E}\right)$. Both species have been noted at a water depth of $0.5-1 \mathrm{~m}$ and $S$. sticticus has also been noted directly below the water line in this water body (Poznańska et al., 2010). The reservoir is inhabited by a rich benthic community due to its high trophic state and good oxygen conditions associated with a short water retention time (4-5 days) (Poznańska et al., 2009). The reservoir often experiences regular and irregular water-level fluctuations up to $\mathrm{ca} 1 \mathrm{~m}$ (Poznańska et al., 2010), resulting from inter-seasonal differences in precipitation, dam operation (e.g. flood control) and sometimes maintenance of the dam infrastructure. Thus, populations inhabiting this water body often experience common water-level fluctuations and therefore are suitable for our study. Chironomids and oligochaetes were used in the experiments after $24 \mathrm{~h}$ of acclimation to laboratory conditions. Both species were macroscopically distinguished before the experiments and their taxonomic identity was confirmed after the test. Oligochaeta were classified on the basis of their morphological traits according to Kasprzak (1981) and Timm (1999). Because the majority of the species of chironomid larvae do not differ in their external morphology (Jabłońska-Barna et al., 2012), species identification was based mainly on the karyotype characteristics of the salivary gland chromosomes (Michailova, 1989), as well as on the morphology of pupae and adults. Some larvae were fixed in alcohol:acetic acid (3:1) mixture for the cytogenetic analysis. Another group was reared to obtain pupae and adults, and also fixed after reaching a desired stage. Chromosome preparations were done using the routine aceto-orcein method (Michailova, 1989). The standardisation of the banding pattern was carried out according to Michailova (1989). Adults, pupae and larvae were mounted on slides for morphological analysis according to Wiederholm (1989) and Langton (1991).

\section{Experimental conditions}

We collected sandy substratum (ca 10-cm-thick surface layer, mean $( \pm \mathrm{SD})$ grain diameter: $0.3 \pm 0.08 \mathrm{~mm}$ ) from the shallow, floodplain part of the Włocławek Reservoir (the same location as that used for animal collection) at a depth of $0.2-0.3 \mathrm{~m}$. We rinsed and dried the substratum at $60^{\circ} \mathrm{C}$ for $6 \mathrm{~h}$ to remove organic matter and living invertebrates, the presence of which could affect the behaviour of the test organisms.

Mean $( \pm \mathrm{SD})$ air temperature and humidity, sustained by air-conditioning, were $21.7 \pm 1.1^{\circ} \mathrm{C}$ (range $19.3-23.4^{\circ} \mathrm{C}$ ) and $39.3 \pm 8.7 \%(28-59 \%)$, respectively, as established daily using a thermo-hygrometer (EMR812HGN, Oregon Scientific, UK). Water quality, monitored at the beginning and at the end of the tests, using a multimeter Multi340i (except when the water level was too low to insert the probes), was suitable for survival of benthic organisms and did not differ considerably between species and experiments. Dissolved oxygen concentrations and saturations were $8.1 \pm 0.9 \mathrm{mg} \mathrm{l}^{-1} \quad$ (range $6.9-9.5 \mathrm{mg} \mathrm{l}^{-1}$ ) and $92 \pm 6.9 \%(77-100 \%)$, respectively. Temperature was $21 \pm 1.7^{\circ} \mathrm{C}\left(18.4-22.9^{\circ} \mathrm{C}\right), \mathrm{pH}$ amounted to 
$8.4 \pm 0.1 \quad(8.1-8.5)$ and conductivity reached $548 \pm 35.0 \mu \mathrm{S} \mathrm{cm}^{-1}$ (499-666 $\left.\mu \mathrm{S} \mathrm{cm}^{-1}\right)$. We also determined the substratum water content at the end of each test, calculating it from the difference in the weight of a sediment sample (ca $5.5 \mathrm{~g}$ of sandy material) before and after drying it for $24 \mathrm{~h}$ at $100^{\circ} \mathrm{C}$.

We placed the prepared substratum as well as conditioned tap water in experimental containers (i.e. trays, tanks or cylinders used in particular experiments; Fig. 1). Water in the containers was aerated for $24 \mathrm{~h}$, then aerators were removed (to avoid their impact on animal behaviour), test animals were introduced and the experiment was started. The water in the drying containers gradually evaporated, exposing the substratum. Additionally, to hasten the process of drying, we removed a small amount of water (ca $100 \mathrm{ml}$ ) daily from the containers with a syringe. Such a gradual drying allowed the animals to adjust and respond to this environmental stress. In each experiment, a control treatment was conducted under the same conditions but with a stable water level during the test period. We checked animal behaviour and/or survival at the same time in both drying and control treatments. Each species was tested separately. The experimental containers were covered with a 1-mm mesh to allow for collecting and counting emerging adult chironomids. We did not include chironomid pupae in the analyses as they could respond differently to drying and their numbers were insufficient to analyse them as a separate category.

Experiment 1: invertebrate survival in drying sediments

We conducted this experiment in ceramic trays ( $N=10$ for each species and treatment), with 1.5$\mathrm{cm}$ layer of sand and $1.5 \mathrm{~cm}$ of water above the substratum surface (Fig. 1a). We introduced 20

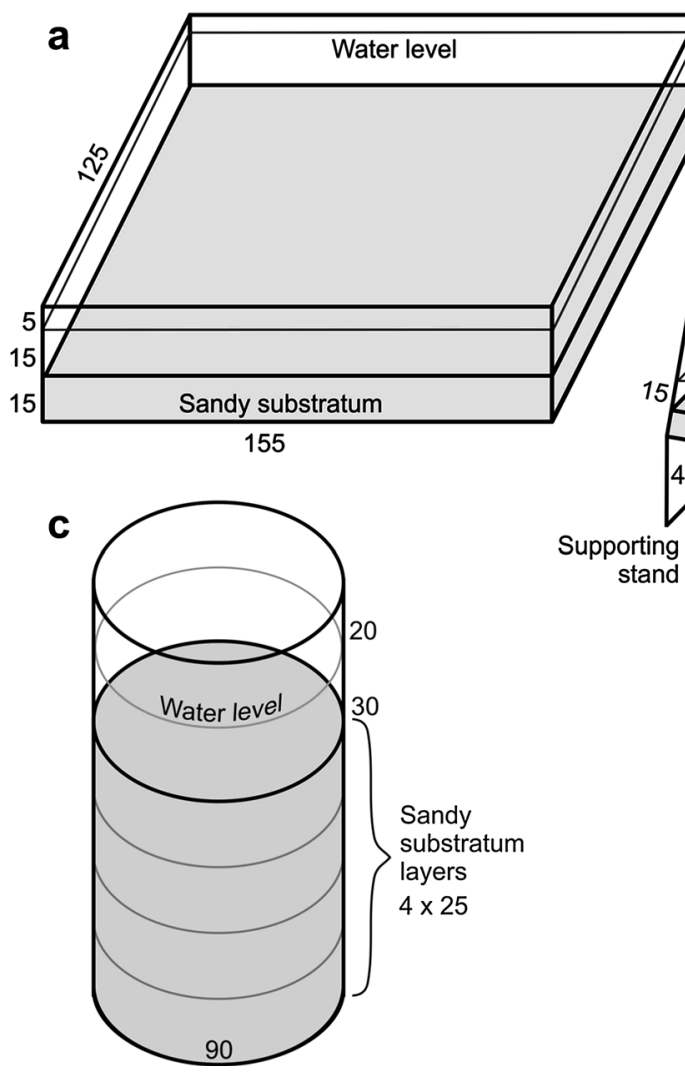

Fig. 1 Experimental apparatus used to test responses of Stictochironomus sticticus and Potamothrix moldaviensis to substratum drying. Ceramic trays used to test animal survival in Experiment 1 (a), glass tanks used to test horizontal migrations in Experiment 2 (b) and glass cylinders used to test vertical migrations in Experiment 3 (c). The dimensions are given in $\mathrm{mm}$ (note that all panels have different scales) 
individuals of each species to separate trays by putting them in random locations on the substratum surface. They quickly started to burrow into the sand. The duration of the experiment and frequency of sampling were determined in preliminary trials, which showed that chironomids were much more resistant to drying than oligochaetes. Therefore, we determined the mortality of chironomids in one randomly selected tray every 2 days starting from the second day of the substratum emersion. Mortality of oligochaetes was determined every day in one tray, starting when small pools of water were present on the emersed surface (i.e. before the substratum was fully emersed) as this was the last moment when all oligochaetes were still alive. On each sampling date, we removed all animals from a randomly selected tray, placed them in a dish filled with fresh water and determined the number of surviving, active individuals. Dead specimens quickly exhibited symptoms of decay and discoloration. Together with checking animal mortality, we measured the water content in the substratum. We conducted this experiment until we obtained the total mortality of animals in the drying trays, which took 7 days for oligochaetes and 12 days for chironomids.

We determined the lethal water content in the substratum associated with 50 and $90 \%$ mortality (LWC50 and LWC90, respectively, with their 95\% confidence intervals) using a probit regression with Schneider-Orelli correction for the control mortality (Finney, 1971). These calculations were carried out using MASS 7.2 package (Venables \& Ripley, 2002) for R statistical computing environment (R Development Core Team, 2015). We considered the LWC values for the two species as statistically different from each other when their $95 \%$ confidence intervals did not overlap.

Experiment 2: horizontal migrations in response to drying

We conducted this experiment in glass tanks $(N=5)$ with a $1.5-\mathrm{cm}$ layer of sand on the bottom and the water level $3 \mathrm{~cm}$ above the substratum surface (Fig. 1b). We divided the tank into three equal zones with glass barriers and introduced 20 individuals of a single species to one of the side zones of the tank. After $24 \mathrm{~h}$, we lifted one of the tank sides so that the animal introduction zone was raised $4.5 \mathrm{~cm}$ above the horizontal plane to imitate the shore inclination
(Fig. 1b). We then removed the barriers so that animals could move freely throughout the tank. In the control tanks, the constant water level of $1.5 \mathrm{~cm}$ in the shallowest place was kept throughout the test. We conducted the experiment until the water level in the drying tanks dropped to the final level indicated in Fig. 1b, which took 7 days. At this point, the substratum consisted of three zones of the same sizes, starting from the raised side of the tank: (1) the dry zone, with humid emersed substratum; (2) the infiltration water zone, with the water level below the emersed substratum surface; and (3) the submerged zone (Fig. 1b). At the end of the experiment, we counted the animals and assessed their mortality in each zone.

We compared substratum water contents between the zones in each treatment using one-way withinsubject ANOVAs (separate for each species). We compared the percentages (arc-sine square root transformed) of animals found in particular tank zones between the drying and control treatments (separately for each zone) using a two-way ANOVA with species and treatment as factors. In the case of significant effects, we applied sequential Bonferroni-corrected $t$ tests as a post hoc procedure. We also used a $t$ test to compare the arc-sine square root-transformed percentages of emerging chironomid adults between both treatments.

We checked the departures of the actual distributions of animals from the random pattern, assuming their equal dispersal among the zones (i.e. their preference for and/or avoidance of particular zones), using sequential Bonferroni-corrected one-sample $t$ tests. These tests compared the mean percentage of animals found in a given tank zone with a theoretical value of $33.3 \%$.

Experiment 3: vertical migrations in response to drying

We ran this experiment in glass cylinders $(N=5)$, filled with a $10-\mathrm{cm}$ layer of sand and a $3-\mathrm{cm}$ layer of water above the substratum surface (Fig. 1c). We introduced 20 individuals of a single species by putting them on the substratum surface and allowing to burrow into sand. One day after the substratum surface in the drying cylinders had been emersed (4-5 days after the animal introduction), we determined the 
number of animals in four $2.5-\mathrm{cm}$ vertical substratum layers.

We compared substratum water contents between the substratum layers in each treatment using one-way within-subject ANOVAs (separate for each treatment and species). We ran a two-way ANOVA with species and treatment as factors to compare arc-sine squareroot-transformed percentages of animals occupying particular substratum layers between the drying and control treatments (separately for each layer). As the oligochaetes never burrowed below $5 \mathrm{~cm}$, we pooled chironomids occurring in $2.5-10 \mathrm{~cm}$ layers for this analysis. To analyse deeply burrowed chironomid individuals, we used sequential Bonferroni-corrected $t$ tests to compare their percentages in separate 2.5-5, 5-7.5 and 7.5-10 cm layers between treatments.

\section{Results}

Experiment 1: invertebrate survival in drying sediments

At the beginning of the experiment and for the duration of control experiments, the mean water content (WC) was ca $19.3 \%$ (initial WC). All individuals of $S$. sticticus survived emersion when the substratum WC was $12.3 \%$ (63\% of the initial WC). The substratum WC at which $90 \%$ of these organisms died (LWC90) was $0.3 \%$ (1.6\% of the initial WC) (Fig. 2), whereas the LWC50 for this species was $2.6 \%$ ( $13.5 \%$ of the initial WC). All individuals died at $0.1 \%$ of WC in the sandy substratum $(0.5 \%$ if the initial value). LWC 90 and LWC50 of P. moldaviensis were distinctly higher (13.9 and $15.9 \%$, respectively, corresponding to 72.0 and $82.4 \%$ of the initial WC) (Fig. 2). All oligochaetes died at the WC of $12.3 \%$ (63.7\% of the initial WC).

Experiment 2: horizontal migrations in response to drying

The final substratum WC in the drying tanks (17-19\%) differed significantly among the tank zones (Table 1), although it was always higher than the value (15.9\%) at which $50 \%$ mortality of oligochaetes took place in Experiment 1 (organism survival). In the control tanks, we observed no significant differences between zones. The mean WC in the control tanks was $19 \%$.

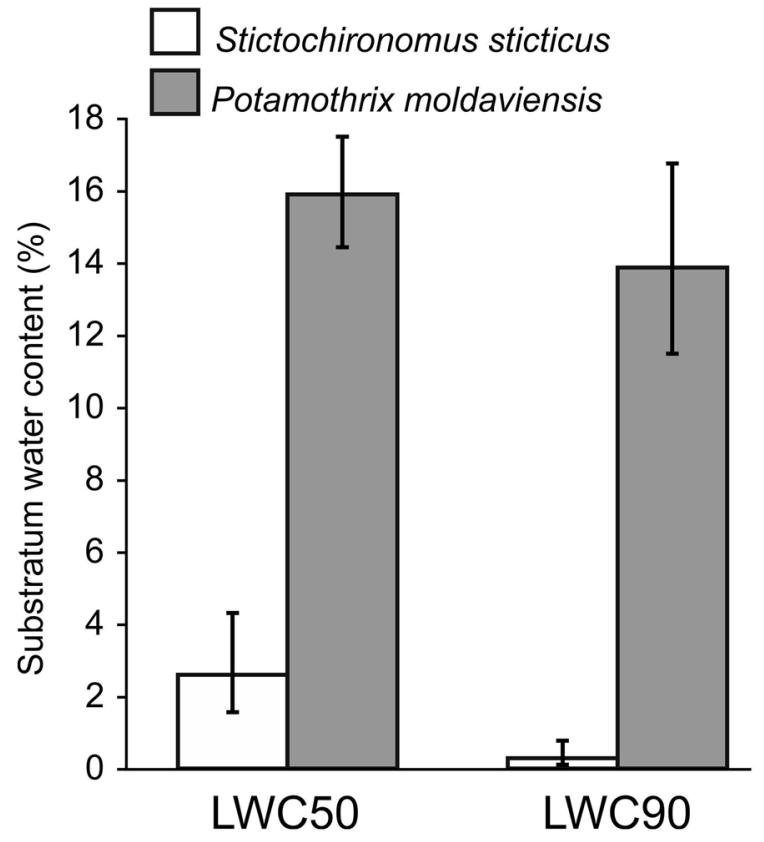

Fig. 2 Substratum water content causing 50 and $90 \%$ mortality (LWC50 and LWC90, respectively, $\pm 95 \%$ confidence intervals) of Stictochironomus sticticus and Potamothrix moldaviensis on sandy substratum (Experiment 1). The values are corrected for the mortality in the control treatment, independent of the effect of drying. $N=10$ trays, 20 individuals in each

The distribution of the tested organisms in the particular zones of the drying tanks depended on the species and emersion, as indicated by significant species $\times$ treatment interactions (Table 2). Neither $S$. sticticus nor $P$. moldaviensis migrated following the decreasing water level. In the drying tanks, $76 \pm 8.7 \%$ (mean $\pm \mathrm{SE}$ ) of $S$. sticticus individuals (significantly more than the expected random value, Table 3) stayed in the dry zone, whereas the infiltration water zone and submerged zone were occupied by $9 \pm 2.8 \%$ (significantly less than expected, Table 3 ) and $15 \pm 6.6 \%$ (no significant departure from the expected random value, Table 3), respectively (Fig. 3a). In the control tanks, the distribution of chironomids did not depart from the random pattern (Fig. 3b; Table 3). The percentages of chironomids emerging as adults (Fig. 3a, b) did not differ between the treatments (Table 2) amounting to $15 \pm 4.4 \%$.

Oligochaetes spread out all over the tanks, similar to the drying and control treatments (Fig. 3c, d), so their distributions were comparable, with no significant departures from the random pattern (Table 3). 
Table 1 Mean substratum water content $[\%]( \pm \mathrm{SE})$ in particular tank zones in Experiment 2 (horizontal migrations)

\begin{tabular}{llllllll}
\hline Species & Treatment & \multicolumn{2}{l}{ Zones } & & & \multicolumn{2}{c}{ ANOVA } \\
\cline { 3 - 6 } \cline { 5 - 7 } & & Dry/upper & Infiltration/middle & Submerged/deeper & df & $F$ & $P$ \\
\hline Stictochironomus sticticus & Drying & $17 \pm 0.4^{\mathrm{a}}$ & $18 \pm 0.3^{\mathrm{b}}$ & $18 \pm 0.3^{\mathrm{b}}$ & 2,8 & 5.81 & $0.028^{*}$ \\
& Control & $19 \pm 0.6^{\mathrm{a}}$ & & $19 \pm 0.4^{\mathrm{a}}$ & 1,4 & 0.44 & 0.546 \\
Potamothrix moldaviensis & Drying & $17 \pm 0.2^{\mathrm{a}}$ & $18 \pm 0.2^{\mathrm{ab}}$ & $19 \pm 0.1^{\mathrm{b}}$ & 2,8 & 14.24 & $0.002^{*}$ \\
& Control & $19 \pm 0.3^{\mathrm{a}}$ & & $19 \pm 0.3^{\mathrm{a}}$ & 1,4 & 0.92 & 0.392 \\
\hline
\end{tabular}

Asterisks indicate statistically significant results in ANOVA. Zones labelled with the same superscript letter did not differ significantly from one another in ANOVA post hoc tests

Table 2 Statistical analysis of the responses of Stictochironomus sticticus and Potamothrix moldaviensis to substratum drying in Experiments 2 (horizontal migrations) and 3 (vertical migrations)

\begin{tabular}{|c|c|c|c|c|c|c|c|}
\hline Experiment & Zone/layer & Test $^{\mathrm{a}}$ & Effect & df & MS & $F / t$ & $P$ \\
\hline \multirow{13}{*}{$\begin{array}{l}\text { Experiment } 2 \\
\quad \text { (horizontal migrations) }\end{array}$} & \multirow[t]{4}{*}{ Dry/upper } & \multirow[t]{4}{*}{ A } & Species & 1 & 0.25 & 5.57 & $0.031 *$ \\
\hline & & & Treatment & 1 & 0.23 & 5.17 & $0.037 *$ \\
\hline & & & Interaction & 1 & 0.39 & 8.80 & $0.009 *$ \\
\hline & & & Error & 16 & 0.04 & & \\
\hline & \multirow{4}{*}{$\begin{array}{l}\text { Infiltration water/ } \\
\text { middle }\end{array}$} & \multirow[t]{4}{*}{ A } & Species & 1 & 0.02 & 0.52 & 0.482 \\
\hline & & & Treatment & 1 & 0.18 & 6.04 & $0.026^{*}$ \\
\hline & & & Interaction & 1 & 0.03 & 0.97 & 0.338 \\
\hline & & & Error & 16 & 0.03 & & \\
\hline & \multirow[t]{4}{*}{ Submerged/deeper } & \multirow[t]{4}{*}{ A } & Species & 1 & 0.21 & 5.36 & $0.034 *$ \\
\hline & & & Treatment & 1 & 0.07 & 1.88 & 0.189 \\
\hline & & & Interaction & 1 & 0.27 & 6.88 & $0.018^{*}$ \\
\hline & & & Error & 16 & 0.04 & & \\
\hline & All zones & $\mathrm{t}$ & Emerging adults & 8 & & 0.39 & 0.710 \\
\hline \multirow{8}{*}{$\begin{array}{l}\text { Experiment } 3 \text { (vertical } \\
\text { migrations) }\end{array}$} & \multirow[t]{4}{*}{$0-25 \mathrm{~mm}$} & \multirow[t]{4}{*}{ A } & Species & 1 & 0.89 & 19.99 & $<0.001 *$ \\
\hline & & & Treatment & 1 & 0.12 & 2.81 & 0.113 \\
\hline & & & Interaction & 1 & 0.01 & 0.13 & 0.724 \\
\hline & & & Error & 16 & 0.04 & & \\
\hline & \multirow[t]{4}{*}{$>25 \mathrm{~mm}$} & \multirow[t]{4}{*}{ A } & Species & 1 & 0.53 & 20.13 & $<0.001 *$ \\
\hline & & & Treatment & 1 & 0.19 & 7.09 & $0.017^{*}$ \\
\hline & & & Interaction & 1 & 0.02 & 0.90 & 0.356 \\
\hline & & & Error & 16 & 0.03 & & \\
\hline \multirow{3}{*}{$\begin{array}{l}\text { Experiment } 3 \\
\quad \text { (S. sticticus only) }\end{array}$} & $25-50 \mathrm{~mm}$ & $\mathrm{t}$ & Treatment & 8 & & 2.14 & 0.064 \\
\hline & $50-75 \mathrm{~mm}$ & $\mathrm{t}$ & Treatment & 8 & & 3.78 & $0.005^{*}$ \\
\hline & $75-100 \mathrm{~mm}$ & $\mathrm{t}$ & Treatment & 8 & & 0.13 & 0.899 \\
\hline
\end{tabular}

Asterisks indicate statistically significant results

a Test type: A-ANOVA, $\mathrm{t}$ - sequential Bonferroni-corrected $t$ tests

Experiment 3: vertical migrations in response to drying

The final substratum $\mathrm{WC}$ in the drying cylinders (15-17\%) did not differ significantly among the substratum layers in the $S$. sticticus variant. However, in the $P$. moldaviensis variant, the $\mathrm{WC}$ in the surface substratum layer $(16 \%)$ was slightly but significantly lower than that in the deeper layers (17\%) (Table 4). Nevertheless, it was always higher than the value (15.9\%) 
Table 3 Comparisons of the distributions of Stictochironomus sticticus and Potamothrix moldaviensis in the substratum zones in Experiment 2 (horizontal migrations) with the theoretical value for the random distribution (33.3\%): one-sample $t$ tests

\begin{tabular}{|c|c|c|c|c|c|c|c|}
\hline \multirow[t]{2}{*}{ Treatment } & \multirow{2}{*}{$\begin{array}{l}\text { Substratum } \\
\text { zone }\end{array}$} & \multicolumn{3}{|c|}{ S. sticticus } & \multicolumn{3}{|c|}{ P. moldaviensis } \\
\hline & & $t$ & df & $P$ & $t$ & df & $P$ \\
\hline \multirow[t]{3}{*}{ Drying } & Dry & 4.35 & 4 & $0.012 *$ & 0.30 & 4 & 0.780 \\
\hline & Infiltration water & 7.58 & 4 & $0.001 *$ & 1.62 & 4 & 0.180 \\
\hline & Submerged & 2.26 & 4 & 0.086 & 1.53 & 4 & 0.200 \\
\hline \multirow[t]{3}{*}{ Control } & Upper & 0.33 & 4 & 0.756 & 0.49 & 4 & 0.653 \\
\hline & Middle & 0.67 & 4 & 0.537 & 1.41 & 4 & 0.231 \\
\hline & Deeper & 1.38 & 4 & 0.241 & 0.39 & 4 & 0.713 \\
\hline
\end{tabular}

Asterisks indicate statistically significant results

Stictochironomus sticticus $\square$ Potamothrix moldaviensis

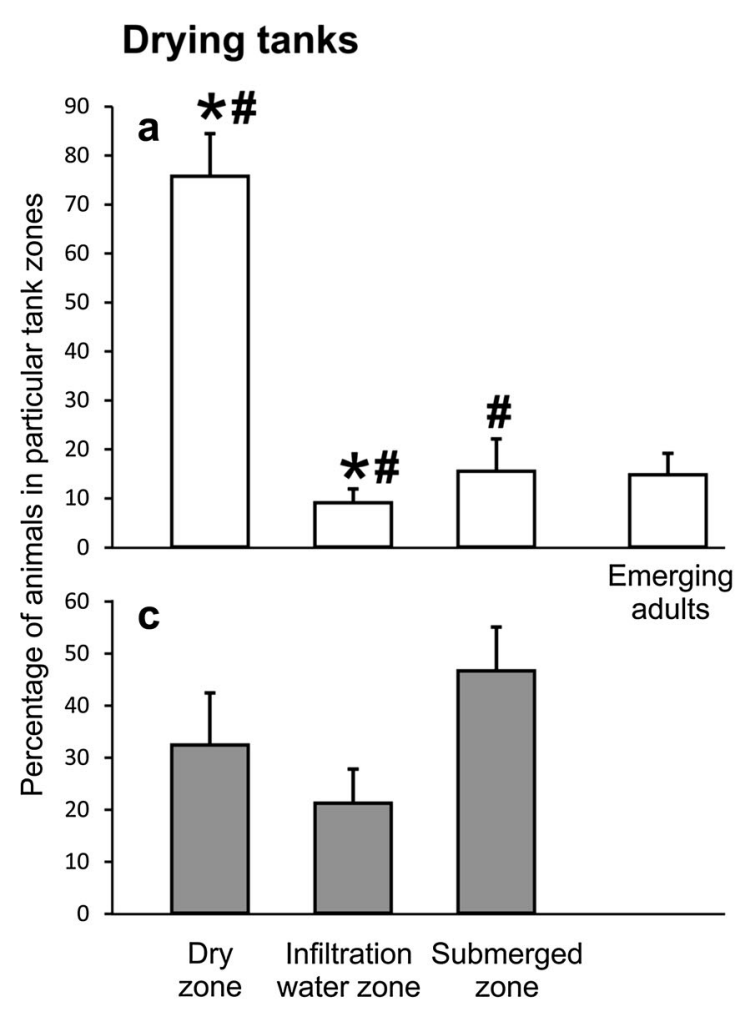

Fig. 3 Mean percentages of Stictochironomus sticticus and Potamothrix moldaviensis $( \pm \mathrm{SE})$ horizontally migrating through substratum zones in the drying and control tanks, as well as percentages of emerging adult chironomids (Experiment 2). $N=5$ tanks, 20 individuals in each. Asterisks above the bars

at which $50 \%$ mortality of oligochaetes took place in Experiment 1 (organism survival). In the control cylinders, we observed no significant differences between the layers and the mean WC was $19.7 \%$.

\section{Control tanks}

b
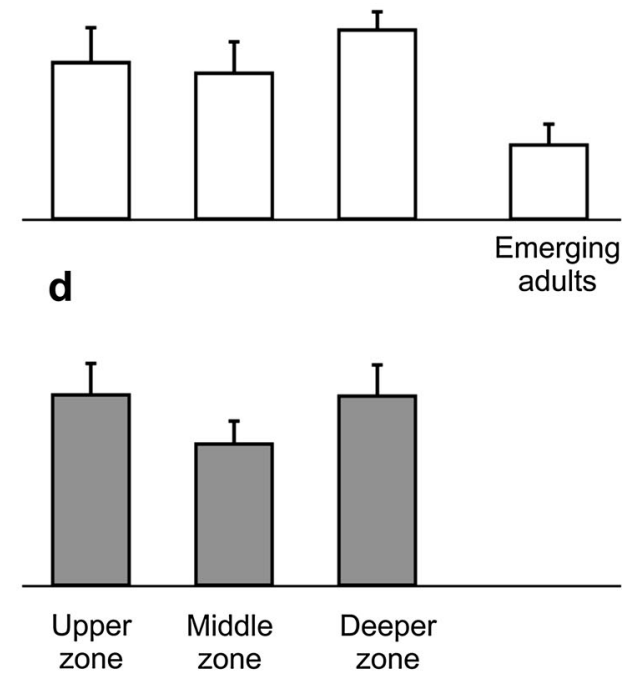

indicate significant departures of organisms percentages in particular tank zones from a theoretical random value of $33.3 \%$. Hashtags indicate animal percentages in the drying treatment, which differed significantly from those in the corresponding control treatment

The percentage of $S$. sticticus in the upper sediment layer was $88 \pm 2.9$ and $69 \pm 2.0 \%$ in the drying and control cylinders, respectively (Fig. 4). It was significantly lower than the occupancy of the upper 
sediment layer by $P$. moldaviensis in both treatments (98 \pm 2.1 and $94 \pm 2.9 \%$, respectively), resulting in a significant species effect (Table 2). Moreover, more individuals of both species occupied the deeper sediment layers in the control treatment $(18 \%)$ than in the drying cylinders (7\%), resulting in a significant treatment effect (Table 2). For chironomids, a significant difference between treatments was observed for the 5-7.5 cm substratum layer (Table 2): 2 and $10 \%$ of individuals occurred in this layer in the drying and control treatments, respectively. For oligochaetes, such difference was noted for the $2.5-5 \mathrm{~cm}$ substratum layer (Table 2): 2 and 6\% of individuals occurred in this layer in the drying and control treatments, respectively. A few chironomids (two and three individuals in the control and drying treatments, respectively) burrowed as deep as $10 \mathrm{~cm}$.

\section{Discussion}

Invertebrate survival in drying sediments

We demonstrated that chironomid larvae of S. sticticus were relatively resistant to substratum drying and this is their main adaptation to such conditions. The substratum water content at which $90 \%$ of these organisms died was $0.3 \%$ ( $1.6 \%$ of the initial WC), which corresponds to completely dry sand. Resistance to drying varies widely within the Chironomidae. For example, larvae of $P$. tritium did not survive in very dry mud except some individuals, which survived 3 days at the substratum water content below $20 \%$ (Dettinger-Klemm, 2003). The author did not report whether the larvae had entered the aestivation state. However, chironomids which can aestivate and are tolerant to the body water loss, e.g. Polypedilum vanderplanki Hinton, 1951, are much more resistant than the above-mentioned species (Watanabe et al., 2002; Frouz et al., 2003; Cranston, 2014). Hence, $S$. sticticus appears as a relatively resistant chironomid species, well adapted to periodically emersed habitats and capable of surviving 5-6 days of the substratum emersion in laboratory conditions. Such resistance was observed to translate into surviving more than 3 weeks of emersion under field conditions, where drying is usually much slower (M. Poznańska, unpublished data). Sediment moisture is an important determinant of macroinvertebrate survival in drying water bodies, as some organisms seem to be able to live in the emersed substratum as long as it remains moist (Stubbington \& Datry, 2013; Verdonschot et al., 2015).

The oligochaete $P$. moldaviensis was far less resistant than larvae of S. sticticus, reaching $90 \%$ mortality at $13.9 \%$ of water content in sandy substratum $(72 \%$ of the initial WC), which translates into moist sand. Moreover, all oligochaetes died at the water content at which all chironomids were still alive. Most not extremely sensitive representatives of the near-shore benthic macroinvertebrates can tolerate such a substratum water content (13-14\%) for comparable periods, including chironomid larvae (Suemoto et al., 2005 and this study), gammarids (Poznańska et al., 2013) and gastropods (Poznańska et al., 2015b). Thus, compared to other benthic species, $P$. moldaviensis turned out to be very sensitive to drying, dying out just 2 days after substratum emersion in laboratory conditions. Probably, its very thin cuticle does not prevent desiccation and results in its low resistance to emersion, observed in our study.

Table 4 Substratum water content $(\%)$ (mean \pm SE) in Experiment 3 (vertical migrations)

\begin{tabular}{|c|c|c|c|c|c|c|c|c|}
\hline \multirow[t]{2}{*}{ Species $^{a}$} & \multirow[t]{2}{*}{ Treatment } & \multicolumn{4}{|c|}{ Substratum layers } & \multicolumn{3}{|c|}{ ANOVA } \\
\hline & & $0-25$ & $25-50$ & $50-75$ & $75-100$ & df & $F$ & $P$ \\
\hline \multirow[t]{2}{*}{ Ss } & Drying & $15 \pm 0.4^{\mathrm{a}}$ & $16 \pm 0.6^{\mathrm{a}}$ & $17 \pm 0.8^{\mathrm{a}}$ & $17 \pm 0.3^{\mathrm{a}}$ & 3,12 & 2.76 & 0.088 \\
\hline & Control & $20 \pm 0.3^{\mathrm{a}}$ & & $20 \pm 0.3^{\mathrm{a}}$ & & 1,4 & 0.43 & 0.546 \\
\hline \multirow[t]{2}{*}{$\mathrm{Pm}$} & Drying & $16 \pm 0.3^{\mathrm{a}}$ & $17 \pm 0.2^{\mathrm{b}}$ & $17 \pm 0.3^{\mathrm{b}}$ & $17 \pm 0.5^{\mathrm{ab}}$ & 3,12 & 4.01 & $0.034 *$ \\
\hline & Control & $20 \pm 0.3^{\mathrm{a}}$ & & $20 \pm 0.2^{\mathrm{a}}$ & & 1,4 & 1.14 & 0.346 \\
\hline
\end{tabular}

Asterisks indicate statistically significant results in ANOVA. Layers labelled with the same superscript letter did not differ significantly from one another in ANOVA post hoc tests

${ }^{a}$ Ss-Stictochironomus sticticus, Pm-Potamothrix moldaviensis 


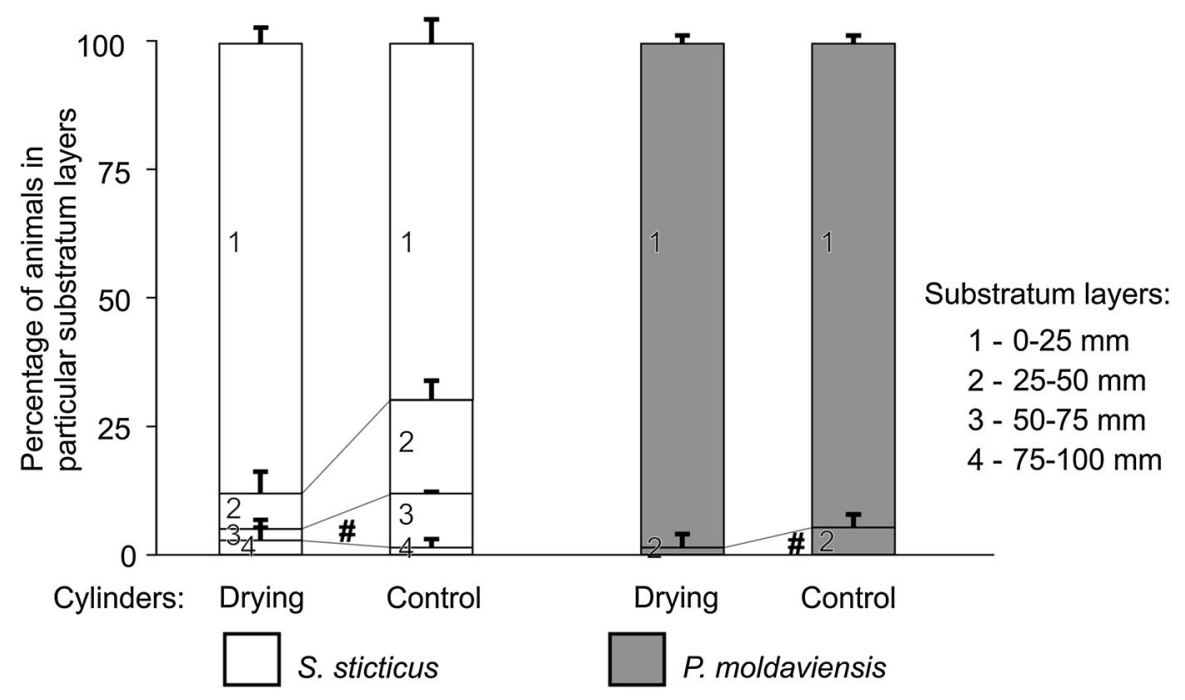

Fig. 4 Mean percentages ( \pm SE) of Stictochironomus sticticus and Potamothrix moldaviensis burrowing into the sediment layers in the drying and control cylinders (Experiment 3, vertical migrations). $N=5$ cylinders, 20 individuals in each. Consecutive numbers on the bars refer to the substratum layers (from

Emergence of adult chironomids

The numbers of emerging adult chironomids were similar in drying and control tanks. This contradicts earlier suggestions that accelerated emergence could be an efficient adaptation to substratum drying, exhibited by taxa living terrestrially as adults (postulated by Dettinger-Klemm, 2003; Tronstad et al., 2005; Verdonschot et al., 2015). Tronstad et al. (2005) demonstrated that insects (including, e.g., Chironomidae, Ceratopogonidae, Dolichopodidae) were capable of emerging from the exposed substratum, but the rate of their emergence did not differ between emersed and inundated areas. Dettinger-Klemm (2003) observed that the emergence was negatively related to the rate of drying. Thus, the fast rate of the water-level decrease might account for the lack of differences in the numbers of emerging adults in our study. This seems particularly important for chironomids, which after pupation float in the water column to the surface and then leave the water as adults.

Horizontal migrations in response to drying

In contrast to our hypothesis, neither $S$. sticticus nor $P$. moldaviensis migrated horizontally following the the surface layer to the deepest one). Hashtags indicate animal percentages in the particular layers of the drying cylinders, which differed significantly from those in the corresponding layers of the control cylinders

decreasing water level resulting from substratum drying. On the contrary, behavioural reaction of $S$. sticticus to drying was diminished movement. In Experiment 2 (horizontal migrations), more individuals of this species stayed in the dry zone in the drying treatment, whereas the distribution of chironomids in the control submerged tanks was random. This indicates that the chironomids in our study were able to migrate in the experimental tanks, but the decreasing water level inhibited their movements. Similarly, the most desiccation-resistant larvae of $P$. vanderplanki did not migrate after decreasing water level (McLachlan, 1983). On the contrary, non-desiccation-tolerant larvae of Chironomus dorsalis Meigen, 1818 and Chironomus imicola Kieffer, 1913 escaped emersion by following the decreasing water level on the mud surface (McLachlan, 1983; Dettinger-Klemm, 2003). Therefore, there seems to be a kind of compromise between the capability of behavioural responses and physiological adaptation to survive emersion. A similar phenomenon was found in freshwater amphipods (Poznańska et al., 2013), which were either resistant to drying, but stayed in the emersed substratum (Pontogammarus robustoides (GO Sars, 1894)) or migrated following the decreasing water level, but died quickly when the experimental design did not 
allow them to escape from drying substratum (Dikerogammarus spp. Stebbing, 1899 and Gammarus fossarum Koch, 1835). However, this is not a general rule, as some snail species are both resistant to drying and exhibit horizontal and vertical migrations following a decreasing water level (Poznańska et al., 2015a, b).

Potamothrix moldaviensis did migrate horizontally in the substratum, but its distribution in the control and drying tanks was similar, showing no directional response to the decreasing water level. It is worth noting that, although $P$. moldaviensis did not respond specifically to substratum drying by following the decreasing water level, it did move horizontally at a distance of at least $24 \mathrm{~cm}$. This movement, starting from the site of initial introduction, led to a random final distribution of the oligochaetes in both drying and control tanks. Horizontal relocations of oligochaetes have also been reported previously, for example earthworms are able to reach drier habitats by active horizontal migration from a flooded site (Mather \& Christensen, 1988; Zorn et al., 2008) and on the aquatic L. hoffmeisteri, which moved horizontally to a better oxygenated part of an experimental tank (Fisher \& Beeton, 1975) as well as the upstream movement of aquatic Oligochaeta (Williams, 1977; Dumnicka, 1996).

Vertical migrations in response to drying

Contrary to our hypothesis, neither S. sticticus nor $P$. moldaviensis migrated vertically towards more humid sediment layers in response to substratum drying. The burrowing behaviour of S. sticticus was more intense in the control tanks. Therefore, similar to the situation observed in Experiment 2 (horizontal migrations), this species appeared to be more active in constantly submerged substratum. According to Stubbington (2012), the reason is probably sediment composition with fine particles, which get compacted during drying and inhibit animal movement. Dole-Olivier et al. (1997) also stated that small interstitial spaces may physically limit migration within sand. Regardless of drying conditions, most larvae burrowed into the shallow layer $(0-2.5 \mathrm{~cm})$, which seems to be a typical burrowing depth for small- and medium-sized littoral chironomid larvae (Int Panis et al., 1996), though Heinis et al. (1994) and Moller Pillot (2009) mostly noted fourth instar larvae of $S$. sticticus at a depth of $2-5 \mathrm{~cm}$. In our experiments, the maximum burrowing depth at which five specimens of S. sticticus larvae were noted was $10 \mathrm{~cm}$. Such a burrowing depth was also noted for overwintering larvae of this species (Moller Pillot, 2009). Generally, irrespective of substratum drying, large species and late instars are usually found deeper in the sediments than small species and early instars (Heinis et al., 1994; van de Bund \& Groenendijk, 1994; Int Panis et al., 1996; Kornijów \& Pawlikowski, 2015). Deeper sediment layers provide their inhabitants with protection against predation and desiccation during emersion events, though at the cost of inferior food and oxygen conditions (Kornijów \& Pawlikowski, 2015). Nevertheless, according to our results, larvae of $S$. sticticus do not seem to be able to respond actively to drying by migrating deeper into the sediments.

The burrowing behaviour of $P$. moldaviensis was mostly limited to the depth of $2.5 \mathrm{~cm}$, with few individuals found deeper in the 2.5- to 5-cm layer. The deeper burrowing occurred almost exclusively in the control tanks. Nevertheless, vertical migration into sediments is a typical escape behaviour of other oligochaete species (Boulton et al., 1992; Merle et al., 1997; Montalto \& Marchese, 2005). Therefore, the lack of such obvious behavioural response in $P$. moldaviensis is unusual. The vertical migration of enchytraeid oligochaetes was diminished in mineral soil in comparison to peat soils (Springett et al., 1970), perhaps because the former substratum was more compact. Merle et al. (1997) demonstrated that tubificoid Naididae colonised the superficial layer $(0-6 \mathrm{~cm})$ of sandy sediments and exposed to fast drying, adopted a passive survival strategy. In contrast, active vertical migrations were observed during the drying period in fine gravel sediments, although the percentage of animals burrowing into the deeper layer (6-15 cm deep) was low. These observations were attributed to much higher compaction of sand in comparison to fine gravel in drying conditions, which may have prevented migrations (Merle et al., 1997). Similarly, Vadher et al. (2015) observed a negative effect of fine sediments on the burrowing of a crustacean Gammarus pulex (Linnaeus, 1758) under drying conditions. The high compaction of particles in emersed sand may also account for the lack of deeper burrowing of $P$. moldaviensis in our experiment. 


\section{Conclusions}

Contrary to our hypothesis postulating the existence of adaptive behavioural responses of near-shore invertebrates to emersion events, typical near-shore representatives of infaunal zoobenthos did not exhibit such reactions. Moreover, $P$. moldaviensis was shown to be very sensitive to drying and died out when substratum water content was still high. In contrast, S. sticticus was able to survive high water loss from sediments, partly confirming our hypothesis assuming the resistance of near-shore invertebrates to drying with regard to this species. Nevertheless, S. sticticus also appears to be less adapted to emersion compared to other, more mobile invertebrates, such as gastropods and gammarids, which exhibit complex strategies consisting of several physiological and behavioural mechanisms (Poznańska et al., 2013, 2015a, b). Therefore, predicted effects of climate change (e.g. frequency and intensity of future droughts) and human activities associated with the regulation of aquatic environment (e.g. river regulation, manipulation of water flow, removal of riparian vegetation) may cause changes in the composition and species distribution of infaunal benthic communities (Richardson et al., 2002; Boulton, 2003; Lind et al., 2006; Leigh et al., 2016). Therefore, sensitive management to mitigate climate change impacts is needed to counteract negative community changes, including adjusting the rate of controllable fluctuations to the demands of aquatic organisms, increasing shoreline shading to reduce evaporation and providing refuges.

Acknowledgements This research was supported by Polish National Science Centre (NSC Grant No. NN304 306840). We are deeply grateful to Christine and Roger Oliver for improving English of our text. Finally, we would like to thank two anonymous reviewers for valuable comments and language corrections which helped us improve the text.

Open Access This article is distributed under the terms of the Creative Commons Attribution 4.0 International License (http:// creativecommons.org/licenses/by/4.0/), which permits unrestricted use, distribution, and reproduction in any medium, provided you give appropriate credit to the original author(s) and the source, provide a link to the Creative Commons license, and indicate if changes were made.

\section{References}

Abbaspour, M., A. H. Javid, S. A. Mirbagheri, F. A. Givi \& P. Moghimi, 2012. Investigation of lake drying attributed to climate change. International Journal of Environmental Science and Technology 9: 257-266.

Anlauf, A., 1990. Cyst formation of Tubifex tubifex (Müller)an adaptation to survive food deficiency and drought. Hydrobiologia 190: 79-82.

Armitage, P. D., P. S. Cranston \& L. C. V. Pinder, 1995. The Chironomidae. Biology and Ecology of Non-biting Midges. Chapman \& Hall, London.

Bazzanti, M., M. Serninara \& S. Baldoni, 1997. Chironomids (Diptera: Chironomidae) from three temporary ponds of different wet phase duration in Central ltaly. Journal of Freshwater Ecology 12: 89-99.

Boulton, A. J., 2003. Parallels and contrasts in the effects of drought on stream macroinvertebrate assemblages. Freshwater Biology 48: 1173-1185.

Boulton, A. J., E. H. Stanley, S. G. Fisher \& P. S. Lake, 1992. Over-summering strategies of macroinvertebrates in intermittent streams in Australia and Arizona. In Robarts, R. D., M. L. Bothwell (eds), Aquatic Ecosystems in Semiarid Regions: Implications for Resource Management. NHRI Symposium Series 7. Environment Canada, Saskatoon, Saskatchewan: 227-237.

Brauns, M., X. F. Garcia \& M. T. Pusch, 2008. Potential effects of water-level fluctuations on littoral invertebrates in lowland lakes. Hydrobiologia 613: 5-12.

Brinkhurst, R. O. \& D. G. Cook, 1980. Aquatic oligochaete biology. Proceedings of the First International Symposium on Aquatic Oligochaete Biology. Plenum Press, New York.

Collinson, N. H., J. Biggs, A. H. M. J. Corfield, M. J. Hodson, D. Walker, M. Whitfield \& P. J. Williams, 1995. Temporary and permanent ponds: an assessment of the effects of drying out on the conservation value of aquatic macroinvertebrate communities. Biological Conservation 74 : 125-133.

Cornette, R., Y. Kanamori, M. Watanabe, Y. Nakahara, O. Gusev, K. Mitsumasu, K. Kadono-Okuda, M. Shimomura, K. Mita, T. Kikawada \& T. Okuda, 2010. Identification of anhydrobiosis-related genes from an expressed sequence tag database in the cryptobiotic midge Polypedilum vanderplanki (Diptera; Chironomidae). Journal of Biological Chemistry 285: 35889-35899.

Cranston, P. S., 2014. A new putatively cryptobiotic midge, Polypedilum ovahimba sp. nov. (Diptera: Chironomidae), from southern Africa. Austral Entomology 53: 373-379.

Datry, T., R. Corti \& M. Philippe, 2012. Spatial and temporal aquatic-terrestrial transitions in the temporary Albarine River, France: responses of invertebrates to experimental rewetting. Freshwater Biology 57: 716-727.

Dettinger-Klemm, P. M. A., 2003. Chironomids (Diptera, Nematocera) of temporary pools-an ecological case study. Ph. D. thesis, Phillips-Universität Marburg, Marburg and Lahn.

Dietz-Brantley, S. E., B. E. Taylor, D. P. Batzer \& A. E. DeBiase, 2002. Invertebrates that aestivate in dry basins of Carolina bay wetlands. Wetlands 22: 767-775.

Dumnicka, E., 1996. Upstream-downstream movement of macrofauna (with special reference to oligochaetes) in the River Raba below a reservoir. Hydrobiologia 334: 193-198.

Dumnicka, E. \& J. Koszalka, 2005. The effect of drought on Oligochaeta communities in small woodland streams. Biologia Bratislava 60: 143-150. 
Dole-Olivier, M.-J., P. Marmonier \& J.-L. Beffy, 1997. Response of invertebrates to lotic disturbance: is the hyporheic zone a patchy refugium? Freshwater Biology 37 : 257-276.

Erséus, C., M. J. Wetzel \& L. Gustavsson, 2008. ICZN rules-a farewell to Tubificidae (Annelida, Clitellata). Zootaxa 1744: 66-68.

Evtimova, V. V. \& I. Donohue, 2016. Water-level fluctuations regulate the structure and functioning of natural lakes. Freshwater Biology 61: 251-264.

Finney, D. J., 1971. Probit Analysis, 3rd ed. Cambridge University Press, Cambridge.

Fisher, J. A. \& A. M. Beeton, 1975. The effect of dissolved oxygen on the burrowing behaviour of Limnodrilus hoffmeisteri (Oligochaeta). Hydrobiologia 47: 273-290.

Fritz, K. M. \& W. K. Dodds, 2004. Resistance and resilience of macroinvertebrate assemblages to drying and flood in a tallgrass prairie stream system. Hydrobiologia 527: 99-112.

Frouz, J. \& J. Matěna, 2015. Desiccation resistance of chironomid larvae. European Journal of Entomology 5: $31-34$.

Frouz, J., J. Matěna \& A. Ali, 2003. Survival strategies of chironomids (Diptera: Chironomidae) living in temporary habitats: a review. European Journal of Entomology 100: 459-465.

Furey, P. C., R. N. Nordin \& A. Mazumder, 2004. Water level drawdown affects physical and biogeochemical properties of littoral sediments of a reservoir and natural lake. Lake and Reservoir Management 20: 280-295.

Furey, P. C., R. N. Nordin \& A. Mazumder, 2006. Littoral benthic macroinvertebrates under contrasting drawdown in a reservoir and a natural lake. Journal of the North American Benthological Society 25: 19-31.

Heinis, F., J. P. Sweerts \& E. Loopik, 1994. Micro-environment of chironomid larvae in the littoral and profundal zone of Lake Maarsseveen I, The Netherlands. Archiv für Hydrobiologie 130: 53-67.

Imhof, J. G. A. \& A. D. Harrison, 1981. Survival of Diplectrona modesta Banks (Trichoptera : Hydropsychidae) during short periods of desiccation. Hydrobiologia 77: 61-63.

Int Panis, L., B. Goddeeris \& R. Verheyen, 1996. On the relationship between vertical microdistribution and adaptations to oxygen stress in littoral Chironomidae (Diptera). Hydrobiologia 318: 61-67.

Jabłońska-Barna, I., A. Kownacki, P. Langton \& P. Michailova, 2012. The external morphology of Chironomus (s. str.) acerbiphilus Tokunaga, 1939 a senior synonym of $C$. crassimanus Strenzke (Diptera, Chironomidae) from Poland. Annales Zoologici 62: 633-638.

Kasprzak, K., 1981. Skąposzczety wodne. Klucze do oznaczania bezkręgowców Polski. PWN, Warszawa (in Polish)

Kornijów, R., S. Radwan, M. Tarkowska-Kukuryk \& G. Kahlan, 2003. Zoobenthos of ecotonal zones in several lakes of different trophic status (the region Polesie Lubelskie, Eastern Poland). Polish Journal of Ecology 51: 237-246.

Kornijów, R. \& K. Pawlikowski, 2015. Three-dimensional microdistribution of Chironomus balatonicus larvae (Chironomidae, Diptera) in soft sediments from the Vistula Lagoon (South Baltic Sea). International Journal of Limnology 51: 343-349.
Kuklińska, B., 1989. Zoobenthos communities of near-shore zone in the Zegrzyński Reservoir. Ekologia Polska 37: 299-318.

Kuklińska, B., 1992. Chironomidae communities of the nearshore zone in Zegrzyński Reservoir, Poland. Netherland Journal of Aquatic Ecology 26: 385-392.

Langton, P. H., 1991. A key to pupal exuviae of West Palaearctic Chironomidae. Cambridgeshire, Huntingdon.

Ledger, M. E. \& A. M. Milner, 2015. Extreme events in running waters. Freshwater Biology 60: 2455-2460.

Leigh, C., N. Bonada, A. J. Boulton, B. Hugueny, S. T. Larned, R. Vander Vorste \& T. Datry, 2016. Invertebrate assemblage responses and the dual roles of resistance and resilience to drying in intermittent rivers. Aquatic Sciences 78: 291-301.

Lind, P. R., B. J. Robson \& B. D. Mitchell, 2006. The influence of reduced flow during a drought on patterns of variation in macroinvertebrate assemblages across a spatial hierarchy in two lowland rivers. Freshwater Biology 51: 2282-2295.

Mather, J. G. \& B. Christensen, 1988. Surface movements of earthworms in agricultural land. Pedobiologia 32: 399-405.

Maraldo, K., H. W. Ravn, S. Slotsbo \& M. Holmstrup, 2009. Responses to acute and chronic desiccation stress in Enchytraeus (Oligochaeta: Enchytraeidae). Journal of Comparative Physiology B 179: 113-123.

McEwen, D. C. \& M. G. Butler, 2010. The effects of water-level manipulation on the benthic invertebrates of a managed reservoir. Freshwater Biology 55: 1086-1101.

McLachlan, A., 1983. Life-history tactics of rain-pool dwellers. Journal of Animal Ecology 52: 545-561.

Merle, C., D. L. Danielopol \& P. Watanamahart, 1997. Impact of environmental conditions on the habitat selection of interstitial-dwelling Tubificids (Oligochaeta). An experimental study. Geobios 30: 91-99.

Moller Pillot, H. K. M., 2009. Chironomidae larvae of the Netherlands and adjacent lowlands. Biology and ecology of the Chironomini. KNNV Publishing, Zeist.

Montalto, L. \& M. Marchese, 2005. Cyst formation in Tubificidae (Naidinae) and Opistocystidae (Annelida, Oligochaeta) as an adaptive strategy for drought tolerance in fluvial wetlands of the Paraná River, Argentina. Wetlands 25: 488-494.

Michailova, P., 1989. The polytene chromosomes and their significance to the systematics of the family Chironomidae, Diptera. Acta Zoologica Fennica 186: 1-107.

Narita, T., 2006. Seasonal vertical migration and aestivation of Rhyacodrilus hiemalis (Tubificidae, Clitellata) in the sediment of Lake Biwa, Japan. Hydrobiologia 564: 87-93.

Neff, R., H. Chang, C. G. Knight, R. G. Najjar, B. Yarnal \& H. A. Walker, 2000. Impact of climate variation and change on Mid-Atlantic Region hydrology and water resources. Climate Research 14: 207-218.

Nickus, U., K. Bishop, M. Erlandsson, C. D. Evans, M. Forsius, H. Laudon, D. M. Livingstone, D. Monteith \& H. Thies, 2010. Direct impacts of climate change on freshwater ecosystems. In Kernan, M., R. W. Battarbee \& B. Moss (eds), Climate Change Impacts on Freshwater Ecosystems. Blackwell Publishing, Oxford: 38-64.

Nilsson, C. \& K. Berggren, 2000. Alterations of riparian ecosystems caused by river regulation. BioScience 50 : 783-792. 
Overpeck, J. \& B. Udall, 2010. Climate change. Dry times ahead. Science 328: 1642-1643.

Poznańska, M., J. Kobak, N. Wolnomiejski \& T. Kakareko, 2009. Shallow-water benthic macroinvertebrate community of the limnic part of a lowland Polish dam reservoir. Limnologica 39: 163-176.

Poznańska, M., J. Kobak, N. Wolnomiejski \& T. Kakareko, 2010. Macrozoobenthos communities from two types of land-water transition zones in a European lowland dam reservoir. Fundamental and Applied Limnology 176: $115-126$.

Poznańska, M., T. Kakareko, M. Krzyżyński \& J. Kobak, 2013. Effect of substratum drying on the survival and migrations of Ponto-Caspian and native gammarids (Crustacea: Amphipoda). Hydrobiologia 700: 47-59.

Poznańska, M., D. Goleniewska, T. Gulanicz, T. Kakareko, Ł. Jermacz \& J. Kobak, 2015a. Effect of substratum drying on the survival and migrations of a freshwater pulmonate snail Planorbarius corneus (Linnaeus, 1758). Hydrobiologia 747: 177-188.

Poznańska, M., T. Kakareko, T. Gulanicz, Ł. Jermacz \& J. Kobak, 2015b. Life on the edge: survival and behavioural responses of freshwater gill-breathing snails to declining water level and substratum drying. Freshwater Biology 60: 2379-2391.

R Core Team, 2015. R: A Language and environment for statistical computing. R Foundation for Statistical Computing, Vienna, Austria. http://www.R-project.org

Richardson, S. M., J. M. Hanson \& A. Locke, 2002. Effects of impoundment and water-level fluctuations on macrophyte and macroinvertebrate communities of a dammed tidal river. Aquatic Ecology 36: 493-510.

Springett, J. A., J. E. Brittain \& B. P. Springett, 1970. Vertical movement of Enchytraeidae (Oligochaeta) in moorland soils. Oikos 21: 16-21.

Strachan, S. R., E. T. Chester \& B. J. Robson, 2015. Freshwater invertebrate life history strategies for surviving desiccation. Springer Science Reviews 3: 57-75.

Stubbington, R., 2012. The hyporheic zone as an invertebrate refuge: a review of variability in space, time, taxa and behaviour. Marine and Freshwater Research 63: 293-311.

Stubbington, R. \& T. Datry, 2013. The macroinvertebrate seedbank promotes community persistence in temporary rivers across climate zones. Freshwater Biology 58: 1202-1220.

Stubbington, R., P. J. Wood, I. Reid \& J. Gunn, 2011. Benthic and hyporheic invertebrate community responses to seasonal flow recession in a groundwater-dominated stream. Ecohydrology 4: 500-511.
Suemoto, T., K. Kawai \& H. Imabayashi, 2005. Dried-up zone as a temporal stock of chironomid larvae: survival periods and density in a reservoir bank. Hydrobiologia 545: $145-152$.

Takada, K., K. Kato \& T. Okino, 1992. Environmental parameters and estivation of Rhyacodrilus (Tubificidae, Oligochaeta) in Lake Suwa, Japan. Ecography 15: 328-333.

Timm, T., 1999. A guide to the Estonian Annelida. Estonian Academy Publishers, Tartu-Tallinn.

Tronstad, L. M., B. P. Tronstad \& A. C. Benke, 2005. Invertebrate responses to decreasing water levels in a subtropical river floodplain wetland. Wetlands 25: 583-593.

Vadher, A. N., R. Stubbington \& P. J. Wood, 2015. Fine sediment reduces vertical migrations of Gammarus pulex (Crustacea: Amphipoda) in response to surface water loss. Hydrobiologia 753: 61-71.

van de Bund, W. J. \& D. Groenendijk, 1994. Seasonal dynamics and burrowing of littoral chironomid larvae in relation to competition and predation. Archiv für Hydrobiologie 132: 213-225.

van Vliet, M. T. H. \& J. J. G. Zwolsman, 2008. Impact of summer droughts on the water quality of the Meuse river. Journal of Hydrology 353: 1-17.

Venables, W. N. \& B. D. Ripley, 2002. Modern applied statistics with S. Springer, New York.

Verdonschot, P. F. M., D. Hering, J. Murphy, S. C. Jähnig, N. L. Rose, W. Graf, K. Brabec \& L. Sandin, 2010. Climate change and the hydrology and morphology of freshwater ecosystems. In Kernan, M., R. W. Battarbee \& B. Moss (eds), Climate Change Impacts on Freshwater Ecosystems. Blackwell Publishing, Oxford: 65-83.

Verdonschot, R. C. M., A. M. van Oosten-Siedlecka, C. J. F. ter Braak \& P. F. M. Verdonschot, 2015. Macroinvertebrate survival during cessation of flow and streambed drying in a lowland stream. Freshwater Biology 60: 282-296.

Watanabe, M., T. Kikawada, N. Minagawa, F. Yukuhiro \& T. Okuda, 2002. Mechanism allowing an insect to survive complete dehydration and extreme temperatures. The Journal of Experimental Biology 205: 2799-2802.

Wiederholm, T., 1989. Chironomidae of the Holarctic region. Keys and diagnoses. Part 3. Adult males. Entomologica Scandynavica Suplement 34, Lund.

Williams, D. D., 1977. Movements of benthos during the recolonization of temporary streams. Oikos 29: 306-312.

Zorn, M. I., C. A. M. Van Gestel, E. Morrien, M. Wagenaar \& H. Eijsackers, 2008. Flooding responses of three earthworm species, Allolobophora chlorotica, Aporrectodea caliginosa and Lumbricus rubellus, in a laboratory-controlled environment. Soil Biology and Biochemistry 40: 587-593. 